\title{
Full Length Article
}

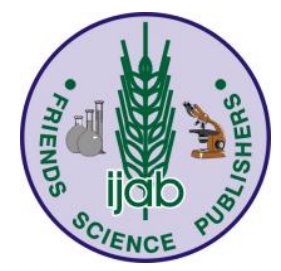

\section{Effect of Citric Acid Acidified Moringa oleifera Seed Meal Based Diet on Nutrients Digestibility and Growth Performance of Cirrhinus mrigala Fingerlings}

\author{
Majid Hussain ${ }^{2,1}$, Syed Makhdoom Hussain ${ }^{*}$, Razia Iqbal'², Arshad Javid ${ }^{3}$, Muhammad Mudassar Shahzad', \\ Muhammad Zubair ul Hassan Arsalan' ${ }^{1}$ and Danish Riaz ${ }^{1}$ \\ ${ }^{1}$ Fish Nutrition Lab, Department of Zoology, Government College University, Faisalabad, Pakistan \\ ${ }^{2}$ Department of Zoology, University of Gujrat, Gujrat, Pakistan \\ ${ }^{3}$ Department of Wildlife and Ecology, University of Veterinary and Animal Sciences, Lahore, Pakistan \\ *For Correspondence: drmakhdoom90@gmail.com
}

\begin{abstract}
This research work was conducted to evaluate the effect of citric acid (CA) acidified Moringa oleifera (Lamarck) seed meal (MOSM) based diet on the apparent digestibility coefficients and growth performance of Cirrhinus mrigala (Hamilton, 1822) fingerlings. MOSM based diet was sub-divided into one control diet ( $0 \% \mathrm{CA})$ and five test diets, each supplemented with 1,2 , 3, 4 and 5\% CA, respectively. Ten fingerlings of C. mrigala were stocked in V-shaped water tanks used in triplicate for each treatment. The feed was given at 5\% live wet body weight of fingerlings for 90 days. Results showed that 3\% CA acidified diet significantly enhanced $(p<0.05)$ the apparent digestibility of crude protein $(67.93 \%)$, crude fat $(71.43 \%)$ and gross energy $(69.00 \mathrm{kcal} / \mathrm{g})$. Diet acidification with CA also significantly $(p<0.05)$ improved overall growth performance of $C$. mrigala fingerlings as compared to control diet. The acidification of MOSM based diet with 3\% CA significantly $(p<0.05)$ increased weight gain (WG; $24.45 \mathrm{~g}$ ), weight gain percent (WG; 255.73\%), specific growth rate (SGR; 1.41$)$ and significantly $(p<0.05)$ decreased feed conversion ratio (FCR; 1.29). In conclusion, 3\% CA acidified MOSM based diet is recommended for better nutrients digestibility and growth performance of C. mrigala fingerlings. (C) 2017 Friends Science Publishers
\end{abstract}

Keywords: Citric acid; Moringa; Nutrient digestibility; Growth; Fingerlings

\section{Introduction}

Production of freshwater fishes has always been dominated by carps (FAO, 2012). Carps are cultured throughout the world in animal aquaculture and well recognized for their adaptability to grow rapidly in confined waters. These fishes are herbivorous and are very selective about their food in nature (Desilva, 2003; Singh et al., 2006). Cirrhinus mrigala is one of major Indian carps commonly consumed throughout Pakistan because of its good meat quality and taste. It has wide distribution in freshwater reservoirs of Pakistan of substantial economic importance and market value (FAO, 2007; Rauf, 2015).

Supplementary feed constitutes more than 50\% expenditure in carp. Therefore, proper feed management is fundamental for enhancing profits (FAO, 2006). Formulation of balanced diets for the successful intensive culture of carps depends upon the knowledge of specific protein requirements for these species. Fishmeal and fish oil are commonly used throughout the world as carp feed, although they are not essential on the purely nutritional basis (Bostock et al., 2010). The furthermore rapid increase in fish oil and fishmeal prices can have negative affect the commercial aquaculture projects (Naylor et al., 2000). Therefore, it is recommended to include plant protein sources in carp diet because of their low cost, abundant availability and herbivorous nature of fishes (Baruah et al., 2007). It is of utmost importance that plant-based ingredients used in aquaculture feed contain certain nutritional characteristics, such as low levels of starch, fiber, anti-nutrients and relatively higher protein contents, high nutrient digestibility, favorable amino acid profile and reasonable palatability (Naylor et al., 2009).

Moringa oleifera is one of the potential plant protein sources for inclusion in aquaculture diets (Chiseva, 2006). The plant of Moringa is high yielding with rapid growth rate. Pods begin to appear after 6 to 8 months of planting but regular fruiting starts after two years and continue for 30 to 40 years (Chuks et al., 2013). Moringa kernel and the fatfree kernel meals have $36.7 \%$ and $61.4 \%$ of crude protein, respectively. It is also potential protein substitute in fishmeal based diets which can minimize the use fishmeal in aquaculture due to its nutritional value of total soluble protein and high pepsin. Because of the favorable amino

To cite this paper: Hussain, M., S.M. Hussain, R. Iqbal, A. Javid, M.M. Shahzad, M.Z.U.H. Arsalan and D. Riaz, 2017. Effect of citric acid acidified Moringa oleifera seed meal based diet on nutrients digestibility and growth performance of Cirrhinus mrigala fingerlings. Int. J. Agric. Biol., 19: 719-725 
acid profile and wide availability throughout the tropical and subtropical regions, Moringa leaves and seeds can be regarded as a potential feed component of fish diet to make aquaculture production cost effective (Tagwireyi et al., 2014).

Digestibility of feed nutrients is a key factor in aquaculture production efficiency and also impacts the environment (NRC, 2011). There are certain factors such as phytate which limits the bioavailability of nutrients present in plant-based fish diets (Francis et al., 2001). Dietary acidification is recommended in fish nutrition to release bound nutrients in phytate (Jongbloed, 1987) because acid secretion in the fish gut is always lower compared to mammals. Lower $\mathrm{pH}$ in fish gut kills the pathogens, increases hydrolysis of phytate, decreases gastric emptying and improves nutrients absorption (Shah et al., 2015). Among the organic acids, CA has been widely used for dietary acidification because of its high buffering capacity and unique flavor (Hossain et al., 2007).

C. mrigala is a fish of great economic importance along with two other Indian major carps such as Labeo rohita and Catla catla. It contributes a major share to the freshwater aquaculture production throughout the Indian subcontinent (Biju et al., 2003). Economic efficiency of commercial aquaculture depends upon the growth rate of fish. Studies performed to explore the growth and feed performance responses to CA acidified diets have shown encouraging results (Sarker et al., 2005; Pandey and Satoh, 2008). Nutrients digestibility and potential for nutrient retention and waste production are factors should be considered for sustainable animal production when considering diet formulations (Hixson, 2014). It was hypothesized that CA supplementation in MOSM based diet improves the growth and nutrient digestibility of $C$. mrigala fingerlings. Therefore, the present study was conducted to investigate the effect of CA acidified MOSM based diets on nutrient digestibility and growth performance of $C$. mrigala fingerlings.

\section{Materials and Methods}

\section{Fish and Experimental Conditions}

Experimental fish Mori (Cirrhinus mrigala) fingerlings were obtained from "Government Fish Seed Hatchery", Faisalabad. Before starting the feeding trial, fingerlings were dipped in $\mathrm{NaCl}(5 \mathrm{~g} / \mathrm{L})$ solution for specific time to make them free of ectoparasites. The fingerlings were acclimatized in the laboratory for 2 weeks period in V-shape like water tanks particularly designed to collect fish fecal material. Throughout this period fingerlings were fed once daily on a basal diet to apparent satiation (Allan and Rowland, 1992). Physical parameters like temperature, dissolved oxygen, and $\mathrm{pH}$ were monitored on a daily basis. Tap water was used during the whole experiment.

\section{Ingredients of Feed and Experimental Diets Formation}

The ingredients of feed were procured from a commercial feed mill and their chemical composition was analyzed (AOAC, 1995) before the formulation of the test diets (Table 1). The ingredients of feed were ground finely to pass through $(0.5 \mathrm{~mm})$ mesh size. All Ingredients of feed were mixed up for five minutes in a food-mixer and fish oil was added subsequently. MOSM based diet was sub-divided into one control (0\%) $0 \mathrm{~g} \mathrm{CA}$ and five test diets, each having $5 \mathrm{~kg}$ weights supplemented with $1 \%(50 \mathrm{~g}), 2 \%(100 \mathrm{~g}), 3 \%(150 \mathrm{~g})$, $4 \%(200 \mathrm{~g})$ and $5 \%(250 \mathrm{~g}) \mathrm{CA}$, respectively. The $100 \mathrm{~g}$ feed per $85 \mathrm{~mL}$ of water was blended into the foodmixer to form a suitable dough, and the pelleting machine was used to process this dough into pellets (Lovell, 1989).

\section{Feeding Schedule and Collection of Sample}

C. mrigala fingerlings were fed twice daily (8:00 am and 2:00 pm) on their respective diet at the rate of $5 \%$ live wet body weight. Each test diet was used in three replicate and fifteen fingerlings were used in each replicate. After two hours feeding session, the unutilized diet from each tank was collected through the valves of tanks. The tanks were washed completely to remove diet particles and water was refilled in each tank. $3 \mathrm{~h}$ after the feeding session, feces were collected from each tank through fecal collection pipes using valves. Utmost care was done to avoid breakdown of fecal strings during fecal collection to make sure minimized nutrient leaching. Fecal material from each tank was oven dried at $60^{\circ} \mathrm{C}$, completely ground and stored in the lab for chemical analysis. A $5 \mathrm{~g}$ fecal material was collected from each tank until the completion of 90 days feeding period.

\section{Chemical Analysis of Feed and Feces}

The samples of feces, experimental diets and feed ingredients were homogenized separately by motor and pestle and were analyzed by standard procedures (AOAC, 1995). Crude protein $(\mathrm{N} \times 6.25)$ was determined by micro Kjeldahl apparatus; moisture by 12 hours oven-drying at $105^{\circ} \mathrm{C}$; crude fat using Soxtec HT2 1045 system through petroleum ether extraction method and gross energy by oxygen bomb calorimeter.

\section{Estimation of Chromic Oxide}

Chromic oxide as an inert marker was added in test diets to determine nutrient digestibility. Chromic oxide content after oxidation of the ash samples of feces and experimental diets with perchloric reagent was estimated by acid digestion method (Divakaran et al., 2002) through UV-VIS 2001 spectrophotometer at $350 \mathrm{~nm}$. 
Citric Acid Improves Performance of Cirrhinus mrigala Fingerlings / Int. J. Agric. Biol., Vol. 19, No. 4, 2017

Table 1: Ingredients composition (\%) of test diets

\begin{tabular}{|c|c|c|c|c|c|c|}
\hline Ingredients & Test Diet-I (control) & Test Diet-II & Test Diet-III & Test Diet-IV & Test Diet-V & Test Diet-VI \\
\hline MOSM & 35 & 35 & 35 & 35 & 35 & 35 \\
\hline Fish meal & 15 & 15 & 15 & 15 & 15 & 15 \\
\hline Soybean meal & 15 & 15 & 15 & 15 & 15 & 15 \\
\hline Wheat flour & 17 & 17 & 17 & 17 & 17 & 17 \\
\hline Rice polish & 8 & 8 & 8 & 8 & 8 & 8 \\
\hline Fish oil & 6 & 6 & 6 & 6 & 6 & 6 \\
\hline Vitamin Premix & 1.0 & 1.0 & 1.0 & 1.0 & 1.0 & 1.0 \\
\hline Mineral Premix & 1.0 & 1.0 & 1.0 & 1.0 & 1.0 & 1.0 \\
\hline Ascorbic acid & 1.0 & 1.0 & 1.0 & 1.0 & 1.0 & 1.0 \\
\hline Chromic oxide & 1.0 & 1.0 & 1.0 & 1.0 & 1.0 & 1.0 \\
\hline Citric acid level & $0 \%$ & $1 \%$ & $2 \%$ & $3 \%$ & $4 \%$ & $5 \%$ \\
\hline Total & 100.0 & 100.0 & 100.0 & 100.0 & 100.0 & 100 \\
\hline
\end{tabular}

MOSM=Moringa seed meal; Citric acid will be used at the expense of wheat flour

\section{Digestibility Calculation}

ADC\% (Apparent nutrient digestibility coefficients) for test diets was determined using standard formula (NRC, 1993).

$$
\operatorname{ADC}(\%)=100-100 \times \frac{\% \text { marker in diet } \times \% \text { minerals in feces }}{\% \text { marker in feces } \times \% \text { minerals in diet }}
$$

\section{Growth Studies}

Fingerlings in each replicate were bulk weighed after the completion of experiment to determine the growth. Fish growth performance was determined using standard formulae:

$$
\begin{aligned}
& \text { Weight gain } \%=\frac{\text { (Final weight }- \text { Initial weight) }}{\text { Initial weight }} \times 100 \\
& \text { FCR } \quad=\frac{\text { Total dry feed intake(g) }}{\text { Wet weight gain }}
\end{aligned}
$$

\section{Statistical Analysis}

The nutrient digestibility and growth performance data were analyzed by one-way analysis of variance (Steel et al., 1996). Tukey's Honesty Significant Difference Test was used to compare differences among treatments and considered significant at $p<0.05$ (Snedecor and Cochran, 1991). Statistical analysis was done using Co-Stat Computer Package (version 6.303, PMB 320, Monterey, CA, 93940 USA).

\section{Results}

Analyzed composition of nutrients in MOSM based diet and feces of $C$. mrigala fingerlings are represented in Table 2 and Table 3. Apparent crude protein, crude fat and gross energy digestibility of $C$. mrigala fingerlings fed MOSM based diets is represented in Table 4. Fingerling fed CA acidified diets showed significantly $(p<0.05)$ improved digestibility of nutrients compared to control diet. Maximum crude protein digestibility (67.93\%) was observed at $3 \% \mathrm{CA}$ level followed by $66.45 \%$ crude protein digestibility at 4\% CA level. However, minimum crude protein digestibility $(48.59 \%)$ was observed in control diet. Whereas, maximum crude fat digestibility (72.43\%) was observed in fingerlings fed at $2 \% \mathrm{CA}$ acidified MOSM based diet. Fingerling fed control diet and 5\% CA acidified MOSM based diet showed significantly $(p>0.05)$ lower crude fat digestibility compared to all other CA acidification levels. Significantly $(p<0.05)$ higher gross energy digestibility $(69.00 \mathrm{kcal} / \mathrm{g})$ was observed in fingerlings fed $3 \%$ CA acidified MOSM based diet. Fingerlings fed 2 and 4\% CA acidified MOSM based diets showed significantly better gross energy digestibility compared to control diet and 1 and 5\% CA acidified MOSM based diets. Fig. 1 shows the relationship between $\mathrm{CA}$ acidified diets and nutrient digestibility parameters. The value of $\mathrm{R}^{2}$ for crude protein $(0.860)$, crude fat $(0.965)$ and gross energy $(0.884)$ digestibility reveals that more than $85 \%$ variation in abovesaid parameters is explained by CA. Optimum crude protein digestibility $(66.39 \%)$, crude fat digestibility $(71.48 \%)$ and gross energy digestibility $(67.40 \%)$ were revealed at optimal CA levels 4.63, 2.53 and 2.89\%, respectively (Fig. 1).

Growth performance of $C$. mrigala fingerlings fed CA acidified MOSM based diets are presented in Table 5. The results showed that acidification of MOSM based diet with CA significantly improved overall growth performance of C. mrigala fingerlings as compare to control diet. Dietary acidification at 3\% CA level significantly improved WG (24.45 g), WG\% (255.73\%) and SGR (1.41) as compare to other CA levels. FCR value significantly improved at 2, 3 and $4 \% \mathrm{CA}$ level as compare to control, 1 and 5\% CA levels. The relationship between $\mathrm{CA}$ and various growth parameters is presented in Fig. 2. Estimated curve showed change in various growth performance parameters with change in CA in MOSM based diets. $\mathrm{R}^{2}$ value for $\mathrm{WG}$ (0.916), WG\% (0.919), FCR (0.991) and SGR (0.927) revealed that more than $90 \%$ variation in above said parameters is caused by CA.

\section{Discussion}

$M$. oleifera tree is of great economic importance with many uses and found throughout most of the tropical regions (Abbas, 2013). Because of the favorable amino acid profile and wide availability throughout the tropical and subtropical regions (Tagwireyi et al., 2014), 
Hussain et al. / Int. J. Agric. Biol., Vol. 19, No. 4, 2017

Table 2: Analyzed composition of nutrients in MOSM based test diets

\begin{tabular}{|c|c|c|c|c|}
\hline Diets & & Crude protein (\%) & Crude fat $(\%)$ & Gross energy $(\mathrm{kcal} / \mathrm{g})$ \\
\hline \multirow{6}{*}{ Citric acid Levels (\%) } & 0 (Control diet) (Test diet $\mathrm{I})$ & 31.37 & 7.56 & 3.24 \\
\hline & 1 (Test diet II) & 31.36 & 7.56 & 3.25 \\
\hline & 2 (Test diet III) & 31.36 & 7.57 & 3.25 \\
\hline & 3 (Test diet IV) & 31.36 & 7.58 & 3.25 \\
\hline & 4 (Test $\operatorname{diet} V)$ & 31.37 & 7.56 & 3.26 \\
\hline & 5 (Test diet VI) & 31.35 & 7.57 & 3.26 \\
\hline PSE & & 0.06284903 & 0.07929081 & 0.0603846 \\
\hline$p$ & & 0.9999 & 0.0061267 & 0.9999 \\
\hline
\end{tabular}

Table 3: Analyzed nutrients (\%) in feces of $C$. mrigala fingerlings fed MOSM based diets

\begin{tabular}{lllll}
\hline Diets & & Crude protein $(\%)$ & Crude fat (\%) & Gross energy (kcal/g) \\
\hline & 0 (Control diet) (Test diet I) & $17.44 \mathrm{a}$ & $3.65 \mathrm{a}$ & $1.98 \mathrm{a}$ \\
Citric acid Levels (\%) & 1 (Test diet II) & $14.82 \mathrm{~b}$ & $3.00 \mathrm{~b}$ & $1.80 \mathrm{ab}$ \\
& 2(Test diet III) & $14.96 \mathrm{~b}$ & $2.24 \mathrm{c}$ & $1.18 \mathrm{c}$ \\
& 3 (Test diet IV) & $10.71 \mathrm{~d}$ & $2.31 \mathrm{c}$ & $1.07 \mathrm{c}$ \\
& 4(Test diet V) & $11.01 \mathrm{~cd}$ & $2.81 \mathrm{~b}$ & $1.18 \mathrm{c}$ \\
PSE & 5 (Test diet VI) & $11.81 \mathrm{c}$ & $3.62 \mathrm{a}$ & $1.74 \mathrm{~b}$ \\
$p$ & & 0.18052396 & 0.04727297 & 0.04386646 \\
\hline
\end{tabular}

Data are means of three replicates; PSE $=$ pooled $\mathrm{SE}=\sqrt{\mathrm{MSE}} / \mathrm{n}$ (where MSE$=$ mean-squared error)

Table 4: Apparent nutrients digestibility (\%) of C. mrigala fingerlings fed MOSM based diets

\begin{tabular}{lllll}
\hline Diets & & Crude protein $(\%)$ & Crude fat (\%) & Gross energy (kcal/g) \\
\hline & 0 (Control diet) (Test diet I) & $48.59 \mathrm{~d}$ & $55.34 \mathrm{c}$ & $43.51 \mathrm{~d}$ \\
& 1 (Test diet II) & $56.60 \mathrm{c}$ & $63.51 \mathrm{~b}$ & $49.15 \mathrm{c}$ \\
Citric acid Levels (\%) & 2(Test diet III) & $55.63 \mathrm{c}$ & $72.43 \mathrm{a}$ & $66.19 \mathrm{~b}$ \\
& 3(Test diet IV) & $67.93 \mathrm{a}$ & $71.43 \mathrm{a}$ & $69.00 \mathrm{a}$ \\
& 4(Test diet V) & $66.45 \mathrm{ab}$ & $64.41 \mathrm{~b}$ & $65.45 \mathrm{~b}$ \\
PSE & 5(Test diet VI) & $65.40 \mathrm{~b}$ & $56.13 \mathrm{c}$ & $51.01 \mathrm{c}$ \\
$p$ & & 0.45055606 & 0.4932203 & 0.48159793 \\
\hline
\end{tabular}

Data are means of three replicates; $\mathrm{PSE}=$ pooled $\mathrm{SE}=\sqrt{\mathrm{MSE}} / \mathrm{n}$ (where $\mathrm{MSE}=$ mean-squared error)

Table 5: Growth performance of $C$. mrigala fingerlings fed MOSM based test diets

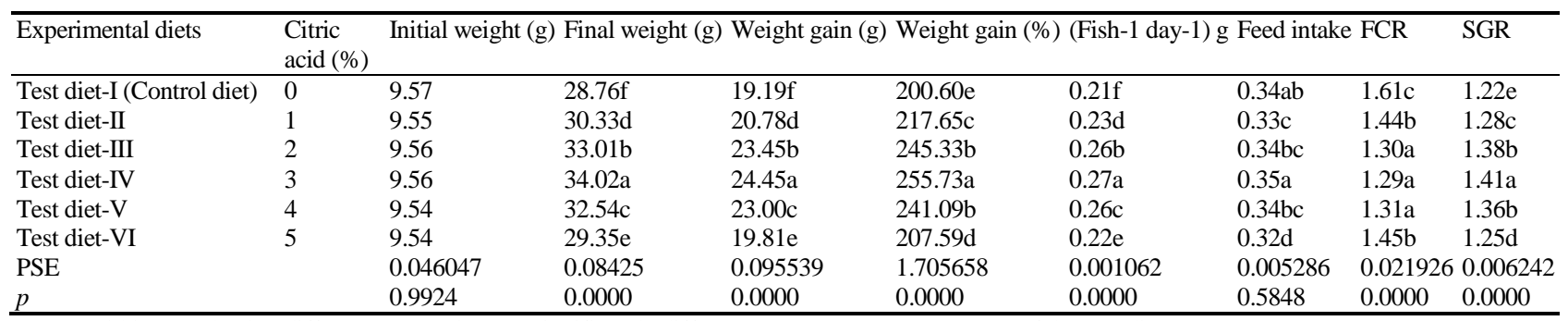

Means within rows having different superscripts are significantly different at $\mathrm{p}<0.05$; Data are means of three replicates

$\mathrm{PSE}=$ pooled $\mathrm{SE}=\sqrt{\mathrm{MSE}} / \mathrm{n}$ (where MSE=mean-squared error)

Moringa seeds were used as protein source for the formulation of MOSM based diets. Acidification of diet with CA release bound nutrients in the diet and also increase its acceptability to fish (Baruah, 2004). Therefore, MOSM based diets were acidified with CA to check their effect on nutrients digestibility and growth performance of $C$. mrigala fingerlings.

The present study revealed that CA acidified MOSM based diets significantly improved overall nutrients digestibility of $C$. mrigala fingerlings. Positive results of CA acidified diets on digestibility of nutrients are also reported by (Baruah et al., 2007; Hussain et al., 2015; Rabia et al., 2017). This may be because CA lowers intestinal $\mathrm{pH}$ to increase the efficiency of digestive enzymes thus improving the digestibility of nutrients. In present study fingerlings fed 3\% CA acidified diet showed significantly higher nutrients digestibility. In agreement with our findings Baruah et al. (2007) reported in his study that 3\% CA acidified and phytase treated diet synergistically enhanced the nutrient digestibility of Labeo rohita juveniles. 
Citric Acid Improves Performance of Cirrhinus mrigala Fingerlings / Int. J. Agric. Biol., Vol. 19, No. 4, 2017
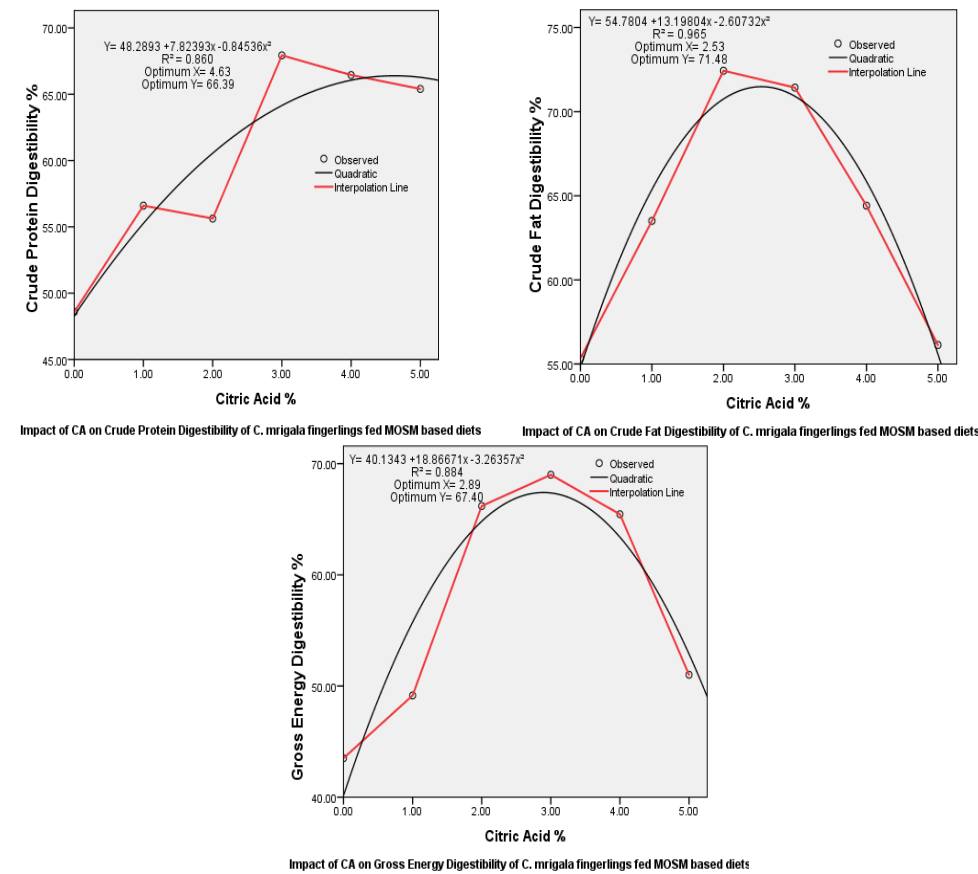

Fig. 1: Relationship between $\mathrm{CA}$ and various nutrient digestibility parameters of Indian major carps fingerlings fed MOSM based diets
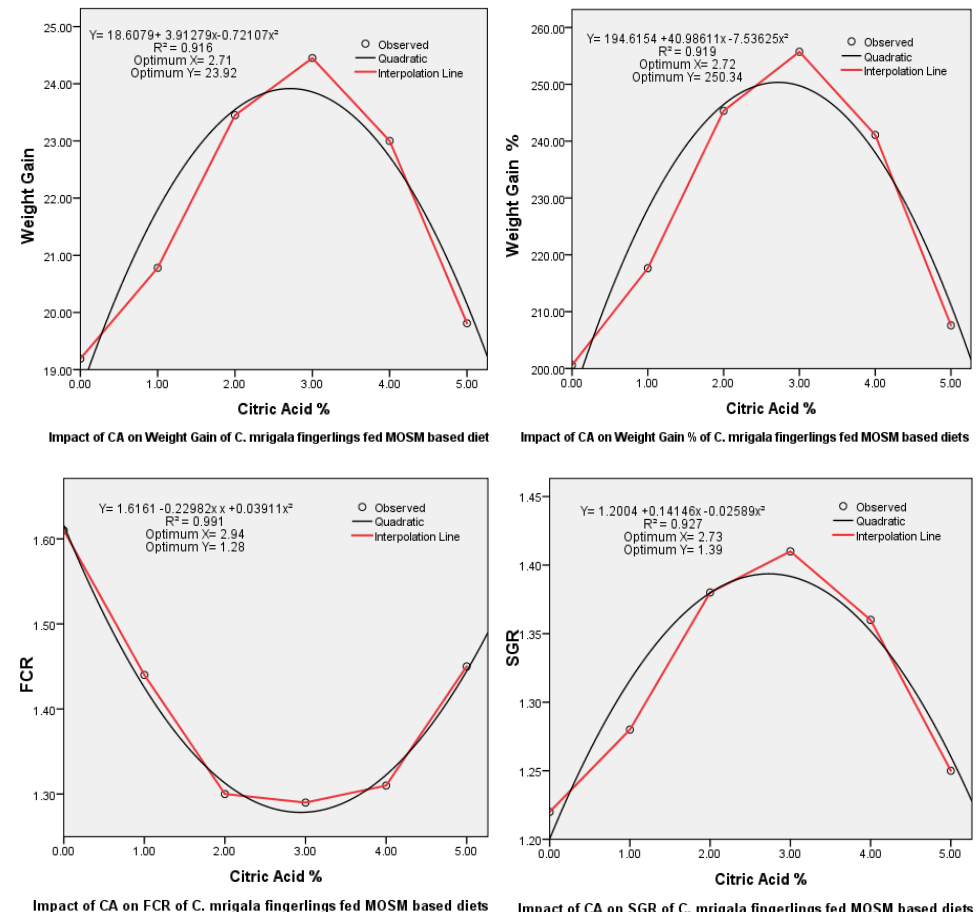

Fig. 2: Relationship between CA and various growth performance parameters of $C$. mrigala fingerlings fed MOSM based diets

These results disagree with findings of Rabia et al. (2017) and Afzal et al. (2016) who concluded that dietary inclusion of $2 \%$ citric acid in sunflower meal-based diet improved the nutrient digestibility in $L$. rohita juveniles. Further disagreeing with us Hussain et al. (2015) reported the significantly higher dry matter, crude protein, crude fat and gross energy digestibility in C. mrigala fingerlings fed 5\% $\mathrm{CA}$ acidified corn gluten meal based diet. This disagreement in results may be because they used different diets and levels of CA in their experiments. 
In the present study $\mathrm{CA}$ acidified diets improved overall growth performance of $C$. mrigala fingerlings as compared to control diet. Improved growth response to CA acidified diet is also reported by Baruah et al. (2007), Afzal et al. and Shah et al. (2016) in Labeo rohita; Hussain et al. (2015) in C. mrigala. This improved growth performance in fish fed CA acidified diet is may be because CA increases the phytate dephosphorylation to release of bound nutrients thus improving growth performance of fish (Baruah et al., 2007). The present study revealed that fingerlings fed $3 \%$ CA acidified diet showed significantly improved WG, WG\%, SGR and FCR. Our results are in agreement with Baruah et al. (2007) and Asrar et al. (2016) who also reported improved WG, SGR and FCR value in L. rohita and $C$. mrigala fed 3\% CA acidified diet, respectively. Sarker et al. (2005) and Shah et al. (2016) also reported improved growth parameters of fish fed 3\% CA acidified diets. In contrary to our results Afzal et al. (2016) and Hussain et al. (2015) reported better growth performance of fish fed 2 and 5\% CA acidified diets.

\section{Conclusion}

Addition of CA in plants based diets release bound nutrients and significantly improves nutrients digestibility and growth performance of fish. Acidification of MOSM based diet with $3 \% \mathrm{CA}$ is recommended for better nutrients digestibility and growth performance of C. mrigala fingerlings.

\section{Acknowledgements}

The authors are thankful to Department of Zoology, University of Gujrat, Pakistan for providing necessary chemicals and feed ingredients. The authors also thank Department of Zoology, Government College University, Faisalabad, Pakistan for providing facility of Fish Nutrition Lab to conduct this research work.

\section{References}

Abbas, T.E., 2013. The use of Moringa oleifera in poultry diets. Turk. J. Vet. Anim. Sci., 37: 492-496

Afzal, M., A. Amanat, S.Z.H. Shah and S.M. Hussain, 2016. Effect of acidification in a phytase sprayed sunflower meal based diet on growth and dietary nutrient digestibility performances of Labeo rohita Juveniles. Pak. J. Zool., 48: 1165-1169

Allan, G.L. and S.J. Rowland, 1992. Development of an experimental diet for silver perch (Bidyanus bidyanus). Austasia Aqua., 6: 39-40

AOAC, 1995. Official Methods of Analysis, 15 $5^{\text {th }}$ edition, p 1094 Washington, DC: Association of Official Analytical Chemists

Asrar, M., S.M. Hussain, S. Tabassum, I.H. Hussain, N. Aslam. M. Arshsd, M.M. Shahzad, M. Hussain, M.Z. Arsalan and D. Riaz, 2016. Effect of citric acid supplementation on growth parameters of Cirrhinus mrigala fingerlings fed canola meal based test diets. J. Biol. Environ. Sci., 9: 381-389

Baruah, K., 2004. Effect of microbial phytase and acidifiers on the bioavailability of nutrients in the diet of $L$. rohita fingerlings. Master's Thesis. Central Institute of Fisheries Education, Deemed University, ICAR, Mumbai, India
Baruah, K., N.P. Sahu, A.K. Pal, K.K. Jain, D. Debnath and S.C Mukherjee, 2007. Dietary microbial phytase and citric acid synergistically enhances nutrient digestibility and growth performance of Labeo rohita (Hamilton) juveniles at sub-optimal protein level. Aquacult. Res., 38: 109-120

Biju, K.C., P.S. Singru, M.P. Schreibman and N. Subhedar, 2003. Reproduction phase-related expression of GnRH-like immunoreactivity in the olfactory receptor neurons, their projections to the olfactory bulb and in the nervus terminalis in the female Indian major carp Cirrhinus mrigala (Ham.). Gen. Comp. Endocr., 133: 358-367

Bostock, J., B. McAndrew, R. Richards, K. Jauncey, T. Telfer, K. Lorenzen, D. Little, L. Ross, N. Handisyde, I. Gatward and R. Corner, 2010 Aquaculture: global status and trends. Phil. Trans. R. Soc. B., 365: 2897-2912

Chiseva, S., 2006. The growth rates and feed conversion ratios of fry fed conventional fry diets and Moringa oleifera supplemented diets. B.Sc. Dissertation. Bindura University of Science Education, Zimbabwe

Chuks, P.E., B.O. Mgbenka and C.D. Ezeonyejiaku., 2013. Moringa plant and its use as feed in aquaculture development: a review. Anim. Res. Int., 10: $1672-1680$

Desilva, S., 2003. Carps. In: Aquaculture Farming Aquatic Animals and Plants, pp: 68-73. Lucas, J.S. and P.C. Southgate (eds.). Fishing News Book, UK

Divakaran, S., G.O. Leonard and P.F. Lan, 2002. Note on the methods for determination of chromic oxide in shrimp feeds. J. Agric. Food Chem., 50: 464-467

FAO, 2006. Cultured Aquatic Species Information Programme Cirrhinus mrigala (Hamilton, 1822). Fisheries and Aquaculture Department. Food and Agriculture Organization of the United Nations

FAO, 2007. FAO Yearbook of Fishery Statistics, Vol. 100: pp: 55-56. Aquaculture production: In: Food and Agriculture Organization of the United Nations, Rome Italy

FAO, 2012. The State of World Fisheries and Aquaculture 2012, p: 209. Rome

Francis, G., H.P.S. Makkar and K. Becker, 2001. Antinutritional factors present in plant-derived alternate fish feed ingredients and their effects in fish. Aquaculture, 199: 197-227

Hixson, S.M., 2014. Fish Nutrition and Current Issues in Aquaculture: The Balance in Providing Safe and Nutritious Seafood, in an Environmentally Sustainable Manner. J. Aquac. Res. Dev., 5: 234

Hossain, M.A., A. Pandey and S. Satoh, 2007. Effects of organic acids on growth and phosphorus utilization in red sea bream Pagrus major. Fish. Sci., 73: 1309-1317

Hussain, S.M., N. Ahmad, F. Jabeen, A. Javid, N. Aslam, M. Hussain, S. Ahmad, M.Z. Arsalan, D. Riaz and M.M. Shahzad, 2015. Effects of citric acid and phytase supplementation on nutrient digestibility and growth performance of Cirrhinus mrigala fingerlings fed on corn gluten (30\%) meal based diets. Int. J. Biosci., 6: 82-91

Jongbloed, A.W., 1987. Phosphorus in the feeding of pigs. PhD. Thesis. Agricultural University of Wageningen, Wageningen

Lovell, R.T., 1989. Fish Nutrition and Feeding. Van Nostrand Reinhold Co., New York, USA

Naylor, R., R. Hardy, D. Bureau, A. Chiu, M. Elliott, A. Farrell, I. Forster, D.M. Gatlin, R.J. Goldburg, K. Hua and P.D. Nichols, 2009. Feeding aquaculture in an era of finite resources. PNAS, 106: $15103-15110$

Naylor, R.L., R.J. Goldburg, J.H. Primavera, N. Kautsky, M.C.M Beveridge, J. Clay, C. Folke, J. Lubchenco, H. Mooney and M. Troell, 2000. Effect of aquaculture on world fish supplies. Nature 405: 1017-1024

NRC, 1993. Nutrient Requirements of Fish, p: 114. National Research Council. National Academies Press, Washington, USA

NRC, 2011. Nutritional Requirements of Fish and Shrimp. National Research Council. National Academies Press, Washington, USA

Pandey, A. and S. Satoh, 2008. Effects of organic acids on growth and phosphorus utilization in rainbow trout Oncorhynchus mykiss. Fish. Sci., 74: 867-874 
Citric Acid Improves Performance of Cirrhinus mrigala Fingerlings / Int. J. Agric. Biol., Vol. 19, No. 4, 2017

Rabia,S., M. Afzal and S.Z.H. Shah, 2017. Nutrient digestibility performance by rohu (Labeo rohita) juveniles fed acidified and phytase pre-treated sunflower meal-based diet. J. Appl. Anim. Res., 45: 331-335

Rauf, A., 2015. Acute toxicity and effects of malathion exposure on behavior and hematological indices in Indian carp, Cirrhinus mrigala (Hamilton). Int. J. Aquat. Biol., 3: 199-207

Sarker, S.A., S. Satoh and V. Kiron, 2005. Supplementation of citric acid and amino acid-chelated trace element to develop environment-friendly feed for red sea bream, Pagrus major. Aquaculture, 248: 3-11

Shah, S.Z.H., M. Afzal, A. Akmal, M. Fatima and S.M. Hussain, 2016. Effect of citric acid and phytase on growth performance and mineralization of Labeo rohita juveniles fed soybean meal based diet. Int. J. Agric. Biol., 18: 111-116

Shah, S.Z.H., M. Afzal, S.Y. Khan, S.M. Hussain and R.Z. Habib, 2015. Prospects of using citric acid as fish feed supplement. Int. J. Agric. Biol., 17: 1-8
Singh, R.K., P.A. Khandagale, S.L. Chavan and P.H. Sapkale, 2006. The relationship of ova diameter to fertilization rates, hatching rates, survival percentage and specific growth rates in the common carp and Indian major carps. Asian Fish Sci., 19: 257-269

Snedecor, G.W. and W.G. Cochran, 1991. Statistical Methods, $8^{\text {th }}$ edition, p: 503. Iowa State University. Press, Americans, Iowa,.USA

Steel, R.G.D., J.H. Torrie and D.A. Dickey, 1996. Principles and Procedures of Statistics, $3^{\text {rd }}$ edition, pp: 336-352. McGraw Hill International Book Co. Inc., New York. USA

Tagwireyi, T., J.F. Mupangwa, J. Jepsen and P. Mwera, 2014. The effect of feeding heat treated Moringa oleifera (lam) leaf meal on the growth performance of Oreochromis Niloticus (Lam) fry. UNISWA J. Agricult., 17: 14-20

(Received 21 February 2017; Accepted 31 March 2017) 